\title{
The Prophet's Public Budget and its Relevancy to the Indonesian Context
}

\author{
Dodik Siswantoro $^{1^{*}}$ \\ ${ }^{1}$ Faculty of Economics and Business, Universitas Indonesia, Depok 16424, Indonesia \\ *Corresponding Author: dodik.siswantoro@ui.ac.id
}

\begin{abstract}
This research seeks to analyze the relevance of Prophet Muhammad's (peace be upon him) (PBUH) type of governmental budget in the current Indonesian context, in which Muslims constitute the biggest population. In its early stage of development, Islam grew and spread rapidly after the Prophet moved to Medina from Mecca. At that time, the spread of Islam was indirectly supported by a budget. It only took ten years from scratch for the Prophet to reach the stage of doing battle with the Roman Empire. The research method used in this paper is a qualitative method with a postpositive paradigm. The data was collected from secondary sources and discussions of specific issues in news media. The results showed that some components of the public budget, such as ghanima (war booty), fai (booty), and jizya (non-Muslim tithe), need to be modified to be relevant to the current Indonesian context. Other countries have applied ghanima and fai in different ways. However, such other practices as zakat (tithe) and sadaqa (charity) are still relevant to supporting Indonesian economic development.
\end{abstract}

Keywords: Prophet; Public; Budget; Zakat; Indonesia.

\section{INTRODUCTION}

The development of Islam in Medina only took ten years (AD 622-632) from scratch, before Prophet Muhammad (PBUH) passed away. Islamic troops were able to successfully defeat Roman troops, who were the toughest army at that time. This success, however, was indirectly backed up by a systematic and good budget that supported the expansion of Islam at that time. After a forced migration to Medina from Mecca in AD 622, Muslims did not have much money and capital in Medina. However, the people of Medina gave some aid and partnerships in order to help the Muslims develop independently in Medina at the beginning of the settlement ${ }^{1,2}$.

In the early settlement, Prophet Muhammad (PBUH) arranged agreements to such local tribes as the Banu Qainuqa, Quraizah, and Nadhir, and the Jews in Medina. This implies that Islam respected diversity and cooperation among different tribes and followers of different religions. In general, Islam was spread peacefully and harmoniously to others. This also occurred in Mecca before the time when the Prophet was moved forcedly to Medina due to killing trials ${ }^{3}$.

The activities of Prophet Muhammad (PBUH) were directly guided by Allah the Almighty. This includes the order to fight the Quraish tribe, who had previously intimidated the Prophet and the followers in Mecca. In total, almost thirty wars occurred during the presence of the Prophet in Medina, but not every war involved physical contact. Preparing strong troops was another strategy of the Prophet to strengthen their position and authority in that region ${ }^{1}$.

The source of governmental revenue and expenditure is stated in the holy book of the Quran, which was revealed to Prophet Muhammad (PBUH). This includes the determination of ghanima (war booty), which is for soldiers, people, and Prophet Muhammad (PBUH). Prophet Muhammad (PBUH) himself allocated expenditure based on the priority derived from his revelation. There are two types of sources of governmental revenue, restricted and unrestricted allocation. Only the allocation of sadaqa (charity) is unrestricted, while other types have specific allocation of expenditure ${ }^{4}$.

\section{LITERATURE REVIEW}

Smith ${ }^{5}$ acknowledges the excellence of Prophet Muhammad (PBUH) in developing the Arab nation at that time. Many scholars also admire the greatness of the Prophet in developing the Arab kingdom and territory. During the Prophet's life, many clans and nations were conquered and joined with him ${ }^{6,7}$.

The sources of revenue for the Prophet's governmental budget and programs are prescribed in the Quran. This paper describes the sources and expenditures of the governmental budget from subsequent events and the related causes (see Table 1). They are as follows: 


\begin{tabular}{lccccc}
\multicolumn{5}{c}{ Table.1. Time and Event ${ }^{1 \text { (modified) }}$} \\
\hline Year & 614 & 616 & 618 & 620 & 622 \\
Event & Zakat 1 & & & Hijra & Ghanima \\
\hline \hline Year & 624 & 625 & 628 & 630 & 632 \\
Event & Zakat 2 & Fai & & Jizya & All Sadaqa \\
\hline
\end{tabular}

\section{a. Zakat (tithe)}

The first verse that describes zakat is contained in the Quran chapter of Romans verse 39. This verse compares zakat, which can give a multiplier effect to the economy, with interest, which has an opposite effect.

The chapter of Romans describes the conquer of the Romans by the Persians, and states that they would win the battle in the following years. It also describes that Muslims would also win against the people of Mecca in the following years. The Romans were defeated by the Persians (Sasanian Empire) in Jerusalem in AD $614^{8}$. This phenomenon from the chapter of Romans was revealed in AD 614. Then, the Persians were defeated by the Romans in AD 624, and in the same year the Muslims won against the Quraish, the people of Mecca, in the Badr war on March 13, AD 624 ${ }^{9-11}$. Previously, Muslims had migrated from Mecca to Medina in AD 622. Badr is located in the middle between Mecca and Medina ${ }^{1}$.

In the aforementioned verse, zakat was just a recommendation and a comparison to riba (usury). Muslims only paid zakat after the second year from when they had settled in Medina. Zakat was paid one month after the war of Badr in AD 624, which occurred in Ramadhan $2 \mathrm{Hijrah}^{4}$. The obligation to pay zakat is stated in the Quran chapter of Cow, verse 110.

Zakat is the third of the Islamic pillars. The second is shalat (praying). Thus, very often, the obligation of giving zakat is stated together with shalat (it is mentioned 27 times in some verses). Zakat here is zakat on items of wealth, such as gold, chattels, agriculture, and related items ${ }^{12}$.

The allocation of zakat is regulated in the Quran chapter of Repentance, verse 60. It is grouped into eight things. The translation is as follows:

"Zakah expenditures are only for the poor and for the needy and for those employed to collect [zakah] and for bringing hearts together [for Islam] and for freeing captives [or slaves] and for those in debt and for the cause of Allah and for the [stranded] traveler-an obligation [imposed] by Allah. And Allah is Knowing and Wise.”

The zakat fund has a specific allocation, which cannot be used for anything other than specific categories, such as operating (salaries and supporting expenses) or capital expenditures (buildings, roads, and fixed assets). However, the zakat allocation scheme can be used in flexible way. In Indonesia, zakat can be used as a soft loan to the needy rather than as a gift. This is to avoid the mental dependence of zakat receivers on the zakat institution. Nevertheless, zakat cannot be used other than for the eight specific groups as the ultimate goals ${ }^{13}$.

\section{b. Ghanima (war booty)}

The regulation on booty was revealed after the Badr war in AD 624. It is in the Quran chapter of Spoils of War, verse 1. The verse is about when the Prophet's soldiers who were at Badr asked the Prophet about booty allocation. This verse states that the allocation is based on the Prophet's decision. In fact, the Prophet allocated the booty accordingly based on the effort of the soldiers and the guards of the ford ${ }^{14}$.

\section{c. Fai (peace booty)}

The next source of governmental revenue is fai (peace booty). It is described in the Quran chapter of Exile, verses 6-7. Bani Nadhir had broken an agreement with Prophet Muhammad (PBUH), by making cooperation with the Quraish, which threatened Muslims in Medina. In addition, Bani Nadhir said he would kill the Prophet when he visited in the house of Bani Nadhir. This occurred in AD 625 or Shafar $4 \mathrm{H}^{1}$.

Bani Nadhir had to leave the city of Madinah as they broke the agreement with Prophet Muhammad PBUH. All properties of Bani Nadhir came to belong to Prophet Muhammad (PBUH). The Prophet only spent it appropriately for one year then he gave it as sadaqa (charity) into the governmental budget. The allocation of booty was for (1) the Prophet, (2) near relatives, (3) orphans, (4) the poor, and (5) travelers ${ }^{14}$.

This verse explicitly states that the allocation of booty is the fifth of all booties, which was not previously regulated. However, the allocation of peace booty may be regulated based on the Prophet's policy. The allocation for the Prophet was based on this agreement. Specific allocations and ghanima allocation were the fifth allocations. For the Khaybar land, the Prophet only got a share of 1/3,600. All of the Fadak land and Wadi Qura land were allocated to the Prophet, but the management was under Jews ${ }^{1}$.

The order to collect non-Muslim tithes was revealed in AD 630 or $9 \mathrm{H}$. It was in the Quran chapter of 
Repentance, verse 29. This verse was revealed before the war of Tabuk. This was a battle against the Romans in the northern Arab territory. To prepare bigger troops, the Prophet asked other tribes and allies to join the battle. He sent people to Yemen, Bahrain, Rome, Persia, and Barbar to pay jizya and to join the army ${ }^{15}$. The total number of people who joined the troop was almost $30,000^{1}$.

\section{e. Sadaqa (charity)}

Before Prophet Muhammad (PBUH) passed away in AD 632 or $11 \mathrm{H}$, in Medina, he gave a testament that all wealth was given as charity to the government. This is the hadith (narrated by Muslim No. 3303),

"When the Messenger of Allah PBUH passed away, his wives made up their minds to send 'Uthman b.

'Affan (as their spokesman) to Abu Bakr to demand from him their share from the legacy of the Prophet PBUH. (At this), A'isha said to them: 'Hasn't the Messenger of Allah PBUH said: "We (Prophets) do not have any heirs; what we leave behind is (to be given in) charity”?”

This may be one reason why the Islamic government in the era of Prophet Muhammad (PBUH) could get a sufficient budget amount for the government activities. Charity can be a source for governmental budget; the amount of which was huge. This, however, was practiced by Prophet Muhammad (PBUH) after receiving revelation in $\mathrm{AD}$ 612. Almost all of the wealth was used to spread Islam in Mecca. The basis of charity in the governmental budget was that it could make the people give their best wealth ${ }^{16}$.

From the aforementioned description, the budget of the Prophet's era is summarized in Table 2. The biggest source is from ghanima, and the largest part of this is from the Hunain war: 6,000 prisoners; 24,000 camels; 40,000 sheep; and more than 4,000 uqiyah silver coins ( 1 uqiyah $=40$ silver coins). Other wars also gave a big amount of ghanima. In addition, fai also contributes a big amount, such as Khaibar land, Wadil Qura land, and Bani Nadhir property. In addition, the Prophet and governmental structures readily gave charity to support the government's activities. This was also a strong reason why they were able to develop and set up supporting programs to develop their moves and activities ${ }^{1}$.

Table.2. Prophet's Public Budget ${ }^{15(\text { modified) }}$

\begin{tabular}{lrlr}
\hline \multicolumn{1}{c}{ Expenditure } & \multicolumn{2}{c}{ Revenue } \\
\hline $\begin{array}{l}\text { Soldiers } \\
\text { 1/5 for leader }\end{array}$ & $\mathrm{xxx}$ & Ghanima & $\mathrm{xxx}$ \\
$\begin{array}{l}\text { Relatives, orphan, } \\
\text { poor and wayfarer }\end{array}$ & $\mathrm{xxx}$ & $\mathrm{Fai}$ & $\mathrm{xxx}$ \\
$\begin{array}{l}\text { Zakat management } \\
\text { 8 Groups }\end{array}$ & $\mathrm{xxx}$ & Zakat & $\mathrm{xxx}$ \\
Administration & $\mathrm{xxx}$ & $\begin{array}{l}\text { Infaq/sadaqa } \\
\text { Tizya }\end{array}$ & $\mathrm{xxx}$ \\
& & $\mathrm{xxx}$ \\
Total & $\mathrm{xxx}$ & Total & $\mathrm{xxx}$ \\
\hline
\end{tabular}

Zakat is used for specific groups in urgent need for support, such as the poor and the needy. If they can develop themselves, they can also contribute to the government. The velocity of the fund will be quick and is not determined by the wealthier people. The government should also be able to make sure that justice can be enforced.

\section{RESEARCH METHOD}

The research employed a qualitative approach with a postpositive paradigm. The data used is secondary data, which was collected from a literature review on the topic of budget revenue in the Prophetic age. Data was also collected from practices in Indonesia that may be similar in substance to the types of cases in Prophet Muhammad's (PBUH) budget.

Data analysis was conducted by identifying the practices that may be similar to the source types in Prophet Muhammad's (PBUH) budget. Then, the appropriate budget sources were redefined to determine better sources of budget revenue. A triangulation of data was conducted by checking other sources to determine the consistency of the data.

\section{DISCUSSIONS}

The analysis is discussed, in sequence, on the following topics.

a. Zakat

Surprisingly, only $1 \%$ of total zakat has been collected from the projected zakat collection of Rp 217 trillion in $2016^{17}$. In fact, the estimated value of zakat collected can reach up to Rp400 trillion ${ }^{4}$. However, zakat is the third pillar of Islamic principles. It is an obligation for Muslims who have sufficient wealth. For example, if they have a minimum value of wealth equivalent to 85 grams of gold (about Rp42.5 million, 1 gram of gold = Rp500,000 in 
2017).

The government of Indonesia has set up an autonomous national institution to collect zakat, which is called Badan Amil Zakat Nasional (Baznas). They have representatives at province and district, and city levels, but they are not directly under Baznas' monitoring. However, they have to report their activities to Baznas. Baznas, at province and district, and city levels are organized and managed under the local government's authority, but the member structure must be approved by Baznas as the national monitoring body. In Aceh, they have independent organizations, which are not under Baznas' authority. They can appoint the structure members independently. In addition, they do not have report to Baznas at a national level ${ }^{18}$.

The issue with zakat here is that Muslims are negligent in giving zakat. If only $1 \%$ of the zakat fund is collected, this means that approximately only $1 \%$ of Muslims have given zakat. However, in other words, zakat, which is called charity, has a positive effect on social and economic development in Indonesia. In Indonesia, zakat payers receive a tax incentive in the form of a taxable income deduction for zakat. In fact, the incentive is very small and may cause inconvenience to zakat payers ${ }^{18}$.

\section{b. Ghanima}

Ghanima in the Prophet Muhammad's (PBUH) era was defined as the wealth that could be taken after a battle. However, not all leaders of the Islamic kingdom fought a war that resulted in ghanima in the era. When Umar bin Abdul Aziz became a leader in the Islamic kingdom, from AD 717-720, they did not receive ghanima as there was no war in that period. He maximized income from sadaqa and minimized the expenditure for the staff of the kingdom ${ }^{4}$.

In fact, some countries may have used war to get other countries' wealth in the 19th century. With respect to ghanima, Prophet Muhammad (PBUH) only fought back to return the people of Mecca's property. However, European countries expanded their territory and authority for their own interests. European countries occupied some countries in Asia and Africa ${ }^{19}$ :

1. The British occupied Oman, Qatar, Malaysia, Egypt, Sudan, Uganda, and Kenya.

2. The French occupied Syria, Lebanon, Sahara, Guinea, Morocco, Algeria, and Tunisia.

3. The Dutch occupied Indonesia, India, South Africa, and Brazil.

4. The Portuguese occupied Indonesia, the Philippines, Angola, and Mozambique.

5. The Spanish occupied Mexico and the Philippines.

In fact, in the 21st century some big countries use military forces to rule specific countries, such as Iraq and Afghanistan. As a result, their land and the natural resources are exploited by some other parties ${ }^{20}$. After World War II was over, there should have been no more annexation of one country by another for any reason. Each country must respect other countries' territory and authority. Through this, peace and respect can maintain harmony among all countries in the world.

Ghanima, from an economic competitiveness point of view, may be in the form of exporting competitive business or foreign direct investment (FDI). To get profit from exporting products, a company in one country needs to create products with better quality and lower prices. In one example, one country can destroy the national products of another country by selling them at lower prices (dumping sales). This occurred in 1992 when Japanese vehicles were sold to US at a lower price than US-made cars, so the Americans preferred to buy Japanese vehicles than locally made cars. Therefore, this threatened the local vehicle manufacturers. As a result, some local vehicle manufactures were shut down due to their failure to compete ${ }^{21}$.

Some countries have established good state-owned enterprises (SOEs), which can generate income and contribute to the governmental budget revenue. To spread and to strengthen product sales, SOEs can open representative offices and manufacturing sites in other countries. Indirectly, private companies can also contribute to the countries they belong to from their taxes, by expanding and creating branches in other countries. The government also receives revenue from their taxes. These companies are then known as multinational companies (MNCs), and have many representatives in other countries.

In the case of Indonesia, only few SOEs of Indonesia can compete with other countries; for example, Pertamina, an oil company, has offshore mining plants in Malaysia, Algeria, Iraq, France, Italy, Canada, Colombia, Myanmar, Namibia, Tanzania, Gabon, and Nigeria ${ }^{22}$. In addition, Semen Indonesia expanded into Vietnam and other Asian countries $^{23}$. However, Indonesia has some products for export that can compete with other countries' products, such as food, vegetables, and other specific products, but they are not so predominant compared to some other countries. The government of Indonesia should focus on empowering and preparing local companies to be able to compete with other countries.

\section{c. Fai}

Fai, in the Prophet's era, was taken from the wealth of an enemy without a battle. In the current context, it can be in the form of cooperation in exploiting natural resources such as oil, gas, coal, nickel, gold, and copper. Again, 
these activities are predominantly carried out by the companies of foreign countries. In Indonesia, there are a great number of natural resources with precious value. However, the local people and government do not get their proportionate share. Local government should have the chance to exploit natural resources for their benefits in their area.

In Indonesia, profit sharing is based on net profit (revenue-cost recovery). For oil, the ratio is 85 for the government and 15 the contractor. For gas, the ratio is 65 for the government and 35 for the contractor ${ }^{24,25}$. This profit sharing ratio is actually not very profitable since the net income is too small after cost recovery. The government must ascertain that the contractors apply the correct cost-recovery method.

For natural resources, the government only charges royalties with a rate range of 3-7\% (the average is 3\%), and a tax rate of $10 \%$. Dividends are also part of revenue; in case the government has a share in a mining operation. In the case of Freeport McMoran, the final profit sharing for income could be 60:40 (government: Freeport McMoran) ${ }^{26,27}$. However, SOEs should be able to manage the mining operations. It creates a bigger portion of income and better transparency. If the mining of natural resources is done by SOEs, this will directly provide benefits to the Indonesian economy.

\section{d. Jizya}

Jizya is a tithe for non-Muslims. This has a similar purpose to the zakat for Muslims. Only wealthy nonMuslims are subject to jizya. The mechanism for jizya is similar to zakat, which has minimum requirement and is collected on a yearly basis. The purpose is also to cover needs and social problems for non-Muslims. Non-Muslims may claim benefits if they are already old and cannot generate income ${ }^{15}$.

The collection of jizya started in AD 630 (before the Tabuk war) and continued until AD 1856, in the Turkey Utsmani era, for which the leader was Abdul Majid I. At that time, there was a national reformation called Tanzimat, which changed some policies ${ }^{4}$. Since then, no country has applied jizya, even though it is based on Islamic teaching.

In the Indonesian context, the issue of collecting fees from non-Muslims can be a sensitive issue. Even in the case of zakat, only $1 \%$ of Muslims give zakat. Therefore, jizya is a potential issue to be addressed after the maximum level of zakat is being collected. However, zakat can also be allocated to non-Muslims as well ${ }^{28}$.

\section{e. Sadaqa}

In the age of Prophet Muhammad (PBUH), many Muslims gave charity to the government. Then, the government freely managed this fund. Thus far, Indonesia has not put this scheme in place for people to give charity to the government. People cannot give charity to the government for the national budget. Even in the US they have a scheme for people to give charity toward the budget ${ }^{4}$.

To date, the government of Indonesia only provides retail bonds for people to finance the governmental budget. In the Islamic scheme, they propose retail sukuk, which can be bought for Rp1 million. Many people and institutions will buy retail sukuk as long as the rate of return is competitive. However, the government can propose retail sukuk based on waqf for specific projects. Waqf projects should be conducted on a profitable basis, which can generate income that can be used for governmental budget revenue.

\section{CONCLUSION}

The sources of governmental budget types in the era of Prophet Muhammad (PBUH) were very simple and based on sadaqa (charity). Each type of budget revenue and expenditure is based on the Quran (Muslim holy book) and hadiths (the Prophet's sayings).

From these types, zakat (tithe) and sadaqa (charity) can be directly adopted. However, the context of a budget is based on a credit contract or taxation rather than a charity scheme. Therefore, the government of Indonesia only issues bonds for people and gives some interest rate coupons. With respect to taxation, it is used for governmental expenditure, and it may not be possible to identify whether the type is capital or operational expenditure. In addition, people are reluctant to pay tax as they do not see any direct benefits.

Meanwhile, for ghanima (war booty) and fai (peace booty), it can be interpreted that Islamic countries should be able to compete in exporting and expanding its best companies into other countries. In the case of fai, the natural resources of Indonesia should not be mined by foreign companies. SOEs should be able to maximize the potential income from these natural resources.

Jizya is a unique issue as, historically, it was revealed at the end of Prophet Muhammad's (PBUH) life. It has a similar function to zakat in that it can contribute to social and economic development.

\section{REFERENCES}

[1] S Al-Mubarakfuri. Sirah Nabawiyah (translated by A Suwandi). Ummul Qura, Jakarta (2011).

[2] I Hisyam. Sirah Nabawiyah (translated by F Bahri). Darul Falah, Bekasi (2006). 
[3] MSR Al-Buthy. Sirah Nabawiyah (translated by ARS Tamhid). Robbani Press, Jakarta (2003).

[4] D Siswantoro. Prinsip-Prinsip Islam dalam Anggaran Sektor Publik (APBN, APBD dan APBDes yang Islami). Mujahid Press, Bandung (2017).

[5] A Smith. Wealth of Nations. The Modern Library, New York (1937).

[6] WM Watt. Muhammad at Mecca. Oxford University Press, London (1952).

[7] MH Hart. The 100: A Ranking of the Most Influential Persons in History. Carol Publishing Book, New Jersey (1978).

[8] G Avni. The Persian Conquest Jerussalem (614CE) - An Archeological Assessment. Accessed from http://www.bibleinterp.com/articles/pers357904.shtml (2010).

[9] T Nöldeke. Sketches from Eastern History (translated by JS Black). Adam and Charles Black Publisher, London (1892).

[10] EN Luttwak. The Grand Strategy of the Byzantine Empire. Harvard University Press, Massachusetts (2009).

[11] Fouman. The Iranian History Article: Byzantine Assault on Persia. Accessed from http://www.fouman.com/Y/Get_Iranian_History_Today.php?artid=1286.

[12] S Nurhayati, W Wasilah. Akuntansi Syariah di Indonesia, Edisi Ke-3. Salemba Empat, Jakarta (2013).

[13] D Siswantoro, G Anugrah. Effectiveness of Zakat as Deductible Income Tax Regulation in Indonesia. International Zakat Conference, World Zakat Forum, Jakarta (2010).

[14] A Abdullah. Tafsir Ibnu Katsir (translated by A Goffar). Pustaka Ibnu Umar, Bogor (2006).

[15] A Ubaid. Al-Amwal (translated by SB Utomo, H Kurniawan). Gema Insani Press, Jakarta (2006).

[16] IMHK Al-Jamal. Khadijah Perempuan Teladan Sepanjang Zaman (translated by TK Purwasandy). Mizania, Bandung (2015).

[17] K Krisiandi. Zakat Indonesia yang Terhimpun Baru Satu Persen dari Potensi. Accessed from http://nasional.kompas.com/read/2016/07/02/10000301/zakat.indonesia.yang.terhimpun.baru.satu.persen.dari.potensi (2016).

[18] D Siswantoro, S Nurhayati. Response to the prohibition of zakat (tithe) collection by private organization in Aceh, Indonesia. Qudus International Journal of Islamic Studies, 1(2) (2014) 133-143.

[19] M Gilmartin. Colonialism/imperialism. In C Gallaher, CT Dahlman, M Gilmartin, A Mountz, \& P Shirlow. Key Concepts in Political Geography. Sage, London (2009) 115-123.

[20] MG Bouvard. A Brief History of the Wars in Iraq and Afghanistan. Accessed from http://www.utne.com/politics/history-of-the-warsin-iraq-and-afghanistan-ze0z1210zsau (2012).

[21] A Harmon. Japanese Car Firms Found 'Dumping': Autos: The Government Agrees with Domestic Makers that Their Rivals Are Selling Minivans at Unfair Prices in the U.S., Accessed from http://articles.latimes.com/1992-05-20/business/fi-283_1_japanese-auto (1992).

[22] A Ika. Agresif Ekspansi, Pertamina Tambah 9 Aset Baru di Luar Negeri. Accessed from http://bisniskeuangan.kompas.com/read/2016/11/17/102514826/agresif.ekspansi.pertamina.tambah.9.aset.baru.di.luar.negeri (2016).

[23] JPNN. Agresif, Semen Indonesia Ekspansi Kedua di Asia. Accessed from http://www.jpnn.com/news/agresif-semen-indonesiaekspansi-kedua-di-asia (2016).

[24] H Hazuardi, J Setyoko. Indonesian Production Sharing Contract (PSC) Fiscal Regime. PPM Project, The 4th Workshop Cambodia Khmer Basin Case Study, Cambodia (2004).

[25] I Khairul. Skema Bagi Hasil Migas: Negara 85\%, Kontraktor 15\%. Accessed from http://www.kompasiana.com/issonkhairul/skemabagi-hasil-migas-negara-85-kontraktor-15_54fd1cb4a333112b3550f869 (2015).

[26] Katadata Indonesia. Berapa Penerimaan Pemerintah dan McMoran dari Freeport Indonesia?. Accessed http://databoks.katadata.co.id/datapublish/2017/03/09/berapa-penerimaan-pemerintah-dan-mcmoran-dari-freeport-indonesia (2017).

[27] E Suryowati. Dalam 20 Tahun, Penerimaan Negara dari Freeport 15,2 Miliar Dollar AS. Accessed from http://bisniskeuangan.kompas.com/read/2015/01/27/1545478/Dalam.20.Tahun.Penerimaan.Negara.dari.Freeport.15.2.Miliar.Dollar.AS (2015).

[28] Y Qardawi. Hukum Zakat (translated by Aqwam). Lintera Antar Nusa, Jakarta (1996). 